\title{
A periculosidade na decretação de prisão preventiva por furto em Salvador: controle racial e de classe
}

\author{
Dangerousness in the decree of preventive detention \\ for theft in Salvador: racial and class control
}

\section{Bernardo Sodré Carneiro Leão ${ }^{1}$}

Universidade Federal da Bahia - Salvador/BA, Brasil bernardoscleao@hotmail.com

http://lattes.cnpq.br/8285595213437507

https://orcid.org/0000-0002-8131-5578

\section{Alessandra Rapacci Mascarenhas Prado ${ }^{2}$}

Universidade Federal da Bahia - Salvador/BA, Brasil armprado@yahoo.com.br

http://lattes.cnpq.br/2158993363327030

https://orcid.org/0000-0001-9972-6634

Resumo: $\mathrm{O}$ artigo apresenta resultado de pesquisa majoritariamente qualitativa que visou a investigar a seletividade penal nas prisões preventivas decretadas por furto em Salvador em 2018 e partiu do seguinte questionamento: quais os principais fatores considerados na fundamentação do juízo de periculosidade na decretação de prisões preventivas? Considera-se a hipótese de que, além da classe, o racismo é fator determinante para as autoridades judiciárias afirmarem a periculosidade do sujeito e decretarem prisões. Então, foi realizada análise de conteúdo das decisões proferidas nas audiências de custódia em Salvador/BA, constantes no banco de dados do relatório da Defensoria

1 Graduado em Direito pela Universidade Federal da Bahia. Membro do NESP/ UFBA.

2 Professora de Direito Penal na Faculdade de Direito e no PPGD/UFBA. Doutora em Direito Penal (PUC-SP). Mestra em Direito das Relações Sociais (PUC-SP). Integrante do Conselho Penitenciário do Estado da Bahia. Membro do IBCCRIM. Coordenadora do NESP - Núcleo de Pesquisa sobre Sanção Penal/UFBA. 
Pública do Estado da Bahia (DPE/BA, 2019), sob a perspectiva da criminologia crítica, associada à perspectiva racial da questão criminal. Por fim, foi possível observar que a reincidência foi o argumento predominantemente adotado para fundamentar os encarceramentos, bem como que, apesar de o fator racial não ter sido encontrado de forma expressa, as agências judiciais e policiais soteropolitanas funcionam em continuidade do controle colonial. Palavras-chave: Prisão preventiva; furto; periculosidade; seletividade; indicador racial.

ABSTRACT: The article presents the result of a mostly qualitative research that aimed to investigate the criminal selectivity in preventive prisons decreed for theft in Salvador in 2018 and started from the following question: which are the main factors considered in the reasonings of the dangerousness' judgment in the decree of preventive detentions? It is considered the hypothesis that, in addition to class, racism is a determining factor for the judicial authorities to affirm the danger of the subject and to order arrests. Then, it was carried out a content analysis of the decisions rendered in the custody hearings in Salvador/BA, contained in the database of the report of the Defensoria Pública do Estado da Bahia (DPE/BA, 2019), from the perspective of critical criminology, associated with the racial perspective of criminal issue. Finally, it was possible to observe that recidivism was the predominant argument to support the imprisonments, as well as that, although the racial factor was not explicitly found, the judicial and police agencies in Salvador still work in continuity with colonial control.

KeYwords: Preventive prison; theft; dangerousness; selectivity; racial indicator.

SUMÁRıo: Introdução; 1 . A criminologia crítica e a crítica racial no realismo marginal brasileiro; 2 . A prisão preventiva por furto nas audiências de custódia; 2.10 sistema penal cautelar e o encarceramento em massa; 2.2 Seletividade penal e crimes patrimoniais: a periculosidade na prisão preventiva; 2.3 As decisões que decretaram prisões preventivas em números; 3. Raça e classe na fundamentação da prisão preventiva por furto em Salvador; 3.1 Periculosidade do Sujeito e a Necessidade de Inibir a Reiteração Delitiva; 3.2 Ausência de Endereço Certo e a Impossibilidade de Identificação Criminal; 3.3 Onde Está o Aspecto Racial?; Considerações Finais; Referências. 


\section{INTRODUÇÃO}

Em um sistema com 545.060 vagas nas unidades prisionais, 811.107 pessoas estão em situação de cárcere no Brasil, números que fazem o país ter a terceira maior população carcerária do planeta, segundo dados do Departamento Penitenciário Nacional (BRASIL, DEPEN, 2020). Dentre eles, há 234.845 pessoas presas sem condenação, ou seja, em torno de $29 \%$ das pessoas em situação de encarceramento no Brasil se encontram presas provisoriamente, seja preventiva ou temporariamente.

Na Bahia, essa proporção é ainda maior, pois o levantamento mostra que o número de pessoas que estão em situação de encarceramento provisório chega a $49 \%$ do total da população prisional do Estado (são 6.972 do total de 14.150). Em Salvador, mais de 55\% do total de 5.243 pessoas que estão encarceradas na comarca estão provisoriamente presas (2.897 pessoas).

Legitimado pelo direito processual penal, o encarceramento provisório esgota de forma imediata e urgente grande parte do poder punitivo repressivo na América Latina, organizado em um sistema penal "pré-condenatório ou cautelar" (ZAFFARONI, 2014, p. 110). Antes de sentenciar os culpados e aplicar-lhes a pena, tal sistema já seleciona os sujeitos considerados perigosos e determina seu confinamento, por um mero juízo de suspeita e com fundamento nos riscos abstratos que a manutenção do sujeito em liberdade pode causar à sociedade. Apesar das últimas alterações legislativas, que introduziram medidas cautelares como alternativas à prisão provisória e que inseriram a prática das audiências de custódia com o fim de controle da legalidade das medidas cautelares, notadamente da prisão, o número de pessoas presas preventivamente permanece alto.

A partir da análise de estudo feito pelo Instituto Baiano de Direito Processual Penal, em convênio com o Tribunal de Justiça do Estado da Bahia (IBADPP, TJ/BA, 2017), sobre as audiências de custódia realizadas em Salvador, chamou a atenção o destaque dado ao frequente uso da periculosidade do sujeito pelas autoridades judiciárias dentre as fundamentações adotadas na decretação de prisões preventivas.

Da mesma forma, o relatório elaborado pela Defensoria Pública do Estado da Bahia (DPE/BA, 2019), resultante de pesquisa quantitativa 
acerca das audiências de custódias na comarca soteropolitana, anos de 2015-2018, realizada pela Escola Superior da Defensoria Pública do Estado da Bahia (ESDPE/BA), registra dados importantes para a análise dos processos de criminalização e de seleção do público-alvo do sistema penal brasileiro, assim como da forte perseguição direcionada aos crimes patrimoniais.

Diante disso, o presente texto resultou da necessidade de se investigar a seletividade penal nas prisões preventivas decretadas por furto, na comarca de Salvador como ambiente de observação, a partir da seguinte questão: quais os principais fatores considerados na fundamentação do juízo de periculosidade na decretação das prisões preventivas? Então, formula-se a hipótese de que, além da classe, o racismo é fator determinante para as autoridades judiciárias afirmarem a periculosidade do sujeito e decretarem prisões.

Para se alcançar os resultados pretendidos, foi realizada pesquisa documental, consistente na análise de textos escritos, registrados em papel (CELLARD, 2008), os documentos que contêm as decisões proferidas nas audiências de custódia analisadas. Trata-se de uma pesquisa ex-post facto, ou seja, a partir do fato passado, na qual não há controle nem interferência sobre o fenômeno investigado, com o objetivo de "identificar situações que se desenvolveram naturalmente e trabalhar sobre elas como se estivessem submetidas a controles" (GIL, 2008, p. 49).

Assim, realizou-se o que Gil (2008) define como pesquisa explicativa, que busca aprofundar o conhecimento da realidade com a preocupação central de identificar os fatores que contribuem para o acontecimento de determinado fenômeno, no caso, a seletividade penal. É também uma pesquisa descritiva, com objetivo de descrever as características desse fenômeno e buscar relações com outras variáveis, como marcadores raciais e sociais, para identificar de que maneira tais fatores extrajurídicos são utilizados para afirmar a periculosidade do sujeito na decisão que decreta a prisão preventiva.

Como o relatório da DPE/BA (2019) tratou de uma análise quantitativa, optamos por realizar uma investigação majoritariamente qualitativa para verificar a ocorrência prática da seletividade penal no âmbito local, especificamente diante do delito de furto, por ser patrimonial, sem violência ou ameaça, portanto, sem maior lesividade, restando a justificativa 
da decretação da prisão centrada na valoração de critérios subjetivos. Delimitamos o estudo sobre as decisões proferidas em audiência de custódia, devido ao fato de ser o momento de análise dos requisitos legais para a decretação da prisão cautelar.

A pesquisa foi viabilizada pelo acesso fornecido pela DPE à planilha de dados do relatório citado, da qual extraímos os números dos processos das 477 decisões proferidas em sede de audiência de custódia, pelo crime de furto, em Salvador, no ano de 2018, sendo que 433 tratavam isoladamente do delito de furto. Considerando que a coleta teve início em 2019, o recorte temporal foi delimitado em razão de garantir a maior atualidade possível dos dados e no espaço temporal de um ano completo. Desta planilha, em conjunto com a consulta integral dos autos dos processos no sistema e-saj do Tribunal de Justiça do Estado da Bahia, extraímos os dados que serão apresentados ao longo do artigo.

De início, sistematizamos os dados apresentados na planilha do relatório da DPE/BA (2019) acerca dos sujeitos flagranteados com relação às 477 decisões para empreender uma breve análise quantitativa (GIL, 2008), com vistas a expor a frequência do fundamento na periculosidade do sujeito e das justificativas mais utilizadas para caracterizar o sujeito como perigoso, além de quantificar as características raciais e sociais das pessoas presas em flagrante e das cautelarmente encarceradas.

Após isso, por meio da consulta eletrônica aos autos de prisão em flagrante (APF) no sistema e-saj do Tribunal de Justiça do Estado da Bahia, levantamos as 83 decisões $(17,5 \%)$ nas quais houve decretação de prisão preventiva, em uma delas houve concessão de prisão domiciliar, e operamos uma análise qualitativa com o fito de descrever o uso da periculosidade do sujeito nas fundamentações e sua relação com outros fatores, especialmente os marcadores de raça e classe.

Nos demais casos, em 260 (54,5\%), a liberdade provisória foi concedida com outras medidas cautelares, fiança ou ambas; em 98 casos (20,5\%), ela foi concedida sem cautelares nem fiança; em 22 (4,6\%), houve relaxamentos de prisão e, em 12 (2,5\%), arbitramentos de fiança pela autoridade policial. Além desses, não obtivemos acesso a dois APFs, de modo que apenas conseguimos a informação de que foram expedidos alvarás de soltura em ambos, mas sem saber se houve relaxamento da prisão, liberdade provisória ou pagamento de fiança. 
Antes de partir para a fase qualitativa, selecionamos apenas os processos que tratavam exclusivamente do delito de furto e eliminamos as 16 decisões nas quais houve alteração na imputação criminal, seja porque a autoridade judiciária entendeu que se tratava de crime de roubo ou porque houve acusação por mais de um delito, além do furto. Esses 16 casos foram excluídos dessa análise, limitando-a a 67 casos.

Em seguida, submetemos a redação das decisões registradas ao procedimento de análise de conteúdo (BARDIN, 1977), que consiste em tomar como fonte de conhecimento os termos utilizados, sua frequência e disposição na construção e desenvolvimento do discurso (CAMPENHOUDUT; QUIVY, 2005). Pela predominância do juízo de suspeita acerca das características do sujeito, enfocamos o estudo nas decisões que decretaram prisões preventivas para verificar quais fatores as autoridades judiciárias utilizavam para justificar o perigo à ordem pública.

Realizamos, por fim, a análise conjunta dos dados quantitativos raciais e sociais dos sujeitos e dos fundamentos encontrados no conteúdo das decisões judiciais que decretaram prisões preventivas, especialmente as que justificaram na periculosidade do agente, com ênfase nos fatores extrajurídicos de raça e classe.

\section{A CRIMINOLOGIA CRÍtica e A CRÍtica RACIAL NO REALISMO MARGINAL BRASILEIRO}

Nesta pesquisa, partimos da perspectiva da criminologia crítica, cujo enfoque busca a construção de um estudo do fenômeno criminal de modo a inserir o controle social como parte desse fenômeno (BARATTA, 2002). Nesse sentido, abordamos os conceitos de criminalização, periculosidade e seletividade pela crítica à criminologia positivista.

A Escola Positiva Italiana de Criminologia operava uma reflexão pseudocientífica e autônoma do discurso jurídico, com base no paradigma etiológico, uma vez que direcionava seus estudos às causas e origens do fenômeno criminal. A criminalidade era considerada uma patologia, sendo necessário investigar suas causas para buscar uma profilaxia adequada, uma "cura deste mal" (GÓES, 2014, p. 114). Nesse sentido, Lombroso, com influência das teorias evolucionistas, notadamente racistas, elaborou uma definição do sujeito criminoso "consubstanciada na degeneração e 
infantilidade da população nativa do novo continente, que por sua vez embasou o conceito de raça, criado em termos científicos biológicos no início do século XIX” (GÓES, 2015, p. 65).

Nesse contexto, desenvolveu-se a ideia de periculosidade, perigosidade ou temibilidade, inicialmente por Ferri e depois aprofundada por Garofalo. Esse termo representava a quantidade de mal que se podia temer por parte do delinquente ou a sua perversidade constante e atuante. De acordo com a teoria da periculosidade, a pena deveria ser individualizada ao caso concreto, baseada na perigosidade do sujeito, critério que levava em consideração suas características biopsicológicas, físicas e sociais e o delito cometido - os elementos do juízo de periculosidade (ELBERT, 1998).

Na América Latina, segundo Batista (2009), o estudo do fenômeno criminal surge por meio do transplante e da disseminação das ideias do positivismo criminológico nos contextos culturais marginais. Por exemplo, têm-se os estudos de Nina Rodrigues, na sociedade baiana do século XIX, autor que investigava o delito influenciado pelas obras de Lombroso. Baseada na superioridade racial, na antropologia e no darwinismo, a criminologia positiva forneceu a base científica para a desigualdade social e racial experimentada no contexto da colonização latino-americana (GÓES, 2014).

Tanto o sistema penitenciário quanto o pensamento criminológico na América Latina foram forjados pelos discursos jurídicos e criminais europeus, construídos de acordo com suas necessidades, principalmente com base nos interesses das classes dominantes. Diante disso, destaca-se o surgimento do critério da perigosidade para definir quem seriam os sujeitos inadequados para o convívio social, os quais eram considerados social, psicológica e biologicamente inferiores. Conforme revelado pelos relatórios da DPE/BA (2019) e do TJ/BA com o IBADPP (2017), essa noção é adotada até os dias de hoje pelas autoridades judiciárias, especialmente na decretação de prisões preventivas. Ainda são comuns decisões judiciais fundamentadas em juízos de periculosidade para definir os sujeitos que devem ser encarcerados cautelarmente para proteger a sociedade.

Com a superação do estudo biopsicológico e etiológico dos criminólogos positivistas pelo paradigma da reação social, Becker (2008) concebe o desvio como uma etiqueta (um status) atribuída a certos indivíduos em um processo de dupla seleção e criminalização: primeiro, os tipos 
penais estabelecem os bens que merecem proteção e os comportamentos que os ofendem; depois, selecionam-se os sujeitos estigmatizados dentre os que infringem as normas penalmente sancionadas.

Diante das influências desse novo paradigma e do labelling approach, o enfoque da criminologia crítica adota uma abordagem histórica do fenômeno comportamental do desvio, que considera o desenvolvimento das relações de produção ao analisar a relação entre as estruturas sociais e sua funcionalidade. A criminalidade é tida como um "bem negativo" (BARATTA, 2002, p. 161), distribuído na sociedade com base na desigualdade social dos sujeitos e na hierarquia dos interesses protegidos por meio dos processos de criminalização primária (produção de normas) e secundária (aplicação das normas) que compõem o sistema do direito penal. Há uma abordagem crítica ao mito do direito penal como igual por excelência, fantasia que constitui a base da ideologia penal da defesa social. Assim como há uma distribuição desigual dos bens e atributos positivos na sociedade, com base na posição social que o sujeito ocupa, a distribuição dos atributos negativos também segue essa lógica, visto que o direito penal é desigual por excelência.

Diante disso, adotamos a criminologia crítica na base teórica pelo foco nos processos desiguais de distribuição da seleção penal como um bem negativo. Entretanto, mesmo com a ruptura do paradigma etiológico para o da reação social, a criminologia crítica não pode ser importada acriticamente ao contexto marginal por ser uma teoria de bases marxistas estruturada no contexto europeu de conflito de classes, que aponta a reprodução das estruturas de poder no sistema penal sem levar em consideração os fenômenos próprios da realidade na América Latina (ZAFFARONI, 2013).

Aqui, não abordamos a noção de classe social na concepção marxista pura, que classifica os grupos sociais com base na sua posição nas relações de produção. Consideramos "classe" como associação da noção de grupos separados por fronteiras objetivas inscritas na realidade e da classificação coletiva obtida pela soma das estratégias por meio das quais cada indivíduo classifica a si e aos outros. A condição de classe decorre, portanto, dos indicadores materiais das posições nas relações de produção (como renda, moradia e grau de escolaridade) e das representações de cada agente de sua posição e das posições dos outros (BOURDIEU, 2013). 
O estudo deve considerar as peculiaridades da sociedade brasileira, na medida em que seu desenvolvimento sócio-histórico teve as relações de subjugação e hierarquização marcadas mais pelo aspecto racial do que pelo social. A intervenção penal visa manter o pacto social racialmente fundamentado, imposto pelas classes brancas detentoras do poder por meio do controle ostensivo da população negra. Portanto, para investigar o funcionamento do sistema penal no Brasil, devemos considerar o racismo que o estrutura e a relação intrínseca entre encarceramento em massa e escravidão (FLAUZINA, 2006). O processo de extermínio consolidado pelos "padrões de mortalidade, de desaparecimento e de encarceramento da juventude, sobretudo negra e pobre" deve impactar a leitura dos dados sobre encarceramento (DUARTE, FREITAS, 2019, p. 157).

O conceito biológico de "raça", utilizado pelo senso comum central no século XIX, preconizava a diferenciação e hierarquização dos indivíduos estabelecida a partir de suas características fenotípicas (GÓES, 2015; GUIMARÃES, 2011, p. 265). No entanto, “o conceito de raça tomado em sentido biológico é intrinsecamente insustentável" (DUARTE, 1988, P. 92), uma vez que atrelado à dominação pelo poder central e utilizado para marcar uma suposta inferioridade dos povos não-europeus.

Apesar disso, o uso da categoria racial ainda é presente no cotidiano, empregado hoje não no sentido biológico, mas carregado de ideologia, pois esconde uma relação de poder e dominação (MUNANGA, 2004). Com roupagem de classificador social, a noção de raça é utilizada inclusive como estratégia política para pleitear inclusão e reivindicar reparação àqueles historicamente marcados como racialmente inferiores (GUIMARÃES, 2011). No contexto brasileiro, raça é um "termo inadequado de acordo com o estágio atual das ciências biológicas, porém fundamental para nossa colonização e para os discursos científicos, incluindo a criminologia” (GÓES, 2014, p. 2).

Por isso, abordamos raça como resultado de uma construção social, sem fundamentação natural ou biológica, que denota "uma forma de classificação social, baseada numa atitude negativa frente a certos grupos sociais e informada por uma noção específica de natureza, como algo endodertminado" (GUIMARÃES, 2009, p. 11). Um conceito do mundo social, que faz "passar por realidade natural preconceitos, interesses e 
valores sociais negativos e nefastos", e que permite combater o comportamento social que ele enseja, isto é, o racismo - enquanto forma "de explicar diferenças pessoais, sociais e culturais a partir de diferenças tomadas como naturais" (GUIMARÃES, 2009, p. 11).

Conforme Segato (2007), a construção da ideia de raça visa à subjugação e à exploração de um determinado grupo, sendo de onde emana a ordem carcerária, em uma relação de retroalimentação. Não existe sistema penal sem questão racial, não se pode retirar dele o racismo sem transformá-lo em outra coisa. Portanto, a questão criminal no contexto do realismo marginal brasileiro deve considerar as questões de classe propostas pela criminologia crítica em face do paradigma da reação social, mas "a fim de suprir essa debilidade, criminólogas e criminólogos críticos devem assumir o racismo como variável substantiva da constituição do sistema penal brasileiro" (FLAUZINA, 2006, p. 14).

A racialização do sistema penal é percebida, entre outros indicadores, pelos dados atuais acerca da população carcerária brasileira, tendo em vista que, do total de 811.107 pessoas, 201.306 são identificadas como brancas, 103.440 pretas, 318.587 pardas, 5.907 amarelas, 1.229 indígenas e 176.676 não possuem informação (DEPEN, 2020). Em um país no qual a população é identificada como $47,7 \%$ branca, 7,6\% preta e 43,1 parda (IBGE, 2010); apenas $24,8 \%$ das pessoas em situação de cárcere são informadas como brancas, ao passo que 39,2\% são pardas e $12,8 \%$ pretas, totalizando $52 \%$.

Por isso, esta pesquisa investiga a ocorrência prática do fenômeno da seletividade penal no âmbito da atuação das autoridades judiciárias nos processos de criminalização secundária, considerando raça e classe social como fatores estruturantes do sistema penal.

\section{A PRISÃO PREVENTIVA POR FURTO NAS AUDIÊNCIAS DE CUSTÓDIA}

Apesar de Zaffaroni (2013) apresentar as agências policiais como as que exercem diretamente o poder punitivo, pois estão nas ruas vigiando e escolhendo os candidatos e candidatas a serem processados, a agência judicial também possui um papel essencial na seleção dos sujeitos. Além de decidir, dentre as pessoas acusadas, as que serão condenadas ou absolvidas, a autoridade judiciária detém o poder de enclausurar preventivamente os 
sujeitos que afirma serem perigosos a ponto de não poderem responder ao processo em liberdade.

Nesse contexto, a audiência de custódia é o momento em que a autoridade judiciária tem o primeiro contato com o sujeito imputado para decidir sobre sua liberdade ou encarceramento cautelar. Porém, antes da análise dos dados quantitativos e qualitativos referentes ao estudo das decisões proferidas por furto nessas audiências, em Salvador, discutiremos conceitos fundamentais da presente investigação: crimes patrimoniais, prisão preventiva, audiência de custódia e periculosidade.

\subsection{O SISTEMA PENAL CAUTELAR E O ENCARCERAMENTO EM MASSA}

A prisão preventiva é uma medida cautelar processual penal de natureza pessoal, é uma modalidade de prisão provisória, ao lado da prisão temporária. É uma medida de privação provisória da liberdade de locomoção da pessoa investigada ou acusada, decretada por um órgão julgador criminal, no curso da investigação preliminar ou do processo criminal, sem prazo máximo previsto em lei acerca da sua duração.

A Lei ${ }^{0}$ 12.403/2011 trouxe novas medidas cautelares ao Código de Processo Penal, sob o argumento de que o encarceramento preventivo deveria ser decretado em caráter de ultima ratio, diante da insuficiência das demais medidas e da necessidade da prisão do sujeito. Fala-se na priorização de medidas diversas da prisão sempre que possível para resguardar a liberdade do sujeito acusado. No entanto, a liberdade sem restrições cautelares segue excepcional, sendo a regra a decretação da prisão preventiva ou a concessão da liberdade combinada com medidas cautelares (ROMÃO, 2021).

Destaca-se também que, a partir do reconhecimento do estado de coisas inconstitucional e por determinação do Supremo Tribunal Federal (ADPF 347/DF), foram implementadas as audiências de custódia com o escopo de aumentar o controle acerca da legalidade da prisão em flagrante e da decretação da prisão cautelar, além de visar inibir as violências perpetradas por agentes policiais, em um movimento que busca a "descarcerização responsável” (NICORY, 2017, p. 29). 
No entanto, conforme Nicory (2017), a audiência de custódia por si só não tem se revelado como suficiente na consecução de tal objetivo, na medida em que ela não foi acompanhada de uma reforma da cultura jurídica punitiva e carcerária. Lages e Ribeiro (2019) afirmam que, mesmo com a implementação dessas audiências, a excepcionalidade da prisão preventiva continua inobservada pelas autoridades judiciárias. Dentre todas as audiências de custódia realizadas no Brasil de sua implementação até julho de 2017, em torno de 55\% delas resultaram em decretação de prisão preventiva, conforme dados do Mapa das Audiências de Custódia, elaborado pelo Conselho Nacional de Justiça (2017).

Pesquisas sobre audiência de custódia revelam que ela não teve a repercussão prometida em relação à redução do encarceramento preventivo, e acaba por legitimar seu uso exacerbado com maior aparência de legalidade e justiça (IDDD, 2019; FBSP, 2018; CONECTAS, 2017). Tal cautelar ainda é utilizada para "incutir na sociedade a percepção de que juízes, defensores e promotores estão comprometidos com a guerra contra o crime e com a construção de uma sociedade mais segura" (LAGES; RIBEIRO, 2019, p. 27).

Conforme Relatório do Fórum Brasileiro de Segurança Pública, nas entrevistas realizadas com atores envolvidos nas audiências de custódia (SP, RJ, PE, RS, DF), foi

comunicada a existência de um saber profissional acumulado que indica que os operadores da justiça criminal são capazes de 'bater o olho' e reconhecer na aparência e na apresentação corporal do acusado um conjunto de informações relevantes para a sua decisão, o que pode explicar a filtragem racial e a reprodução de um tratamento desigual entre negros e brancos. (2018, p. 298)

Considerando que um dos requisitos legais para decretação da cautelar é o "perigo para a ordem pública”, e que a audiência de custódia permite contato direto da autoridade judiciária com o sujeito que fora preso em flagrante para decidir sobre a manutenção da sua prisão, as características pessoais do sujeito flagrado podem incidir nesse juízo de temibilidade realizado para justificar a necessidade de segregação cautelar. 


\subsection{Seletividade Penal e CRIMES PATRIMoniais: a PERICUlosidade NA PRISÃO PREVENTIVA}

Atualmente, o encarceramento em massa é o instrumento utilizado pelo sistema punitivo brasileiro para manutenção do controle social, econômico e racial, incidindo principalmente nos delitos de drogas e patrimoniais (FLAUZINA, 2006). O elevado rol de crimes contra o patrimônio e as altas penas fixadas a eles apontam para a preocupação dos legisladores em punir condutas que violam a propriedade privada.

Percebe-se a violência direcionada aos crimes cometidos contra bens patrimoniais também nos processos de criminalização secundária, já que 277.263 pessoas estão privadas de liberdade por crimes contra o patrimônio, dentre as com condenação definitiva e as que aguardam julgamento, cerca de 39\% da população carcerária nacional (DEPEN, 2020). Esse cenário revela que o patrimônio é colocado como um dos bens jurídicos mais relevantes, se não o mais relevante, a ser protegido pelas agências penais.

Ademais, apesar de ser um crime sem violência e com pena mínima de um ano de detenção, há uma forte incidência do sistema penal em relação ao furto dentre os crimes patrimoniais. Em Salvador, segundo o relatório da DPE/BA (2019, p. 66), dos 5.588 casos de prisão em flagrante por todos os delitos levados à audiência de custódia, em 2018, 477 correspondem ao crime de furto, seja simples ou na modalidade qualificada ${ }^{3}$.

No contexto brasileiro, Flauzina (2006) afirma que a punição sempre esteve atrelada ao controle patrimonial por uma pequena elite por meio da exploração dos demais. O poder punitivo, aos poucos, passou do privado para o público, mas sempre com a mesma função de manutenção do status quo. A presença histórica da criminalização de condutas que

3 O artigo 155 do Código Penal tipifica como furto simples a conduta de "subtrair para si ou para outrem coisa alheia móvel”, aplicando pena de reclusão de um a quatro anos. $\mathrm{O}$ mesmo artigo prevê que a pena pode ser aumentada em $1 / 3$ se o delito for praticado durante o repouso noturno, além de trazer algumas hipóteses de furto qualificado, ou seja, quando o fato típico é praticado com alguma circunstância específica mais grave, situação para a qual o Código Penal estipula novos patamares de penas mínimas e máximas. (BRASIL. Decreto-Lei 2.848, de 07 de dezembro de 1940. Código Penal. Rio de Janeiro: Diário Oficial da União, 1940). 
trazem prejuízos à acumulação capitalista ou ameaçam romper com a desigualdade estruturante evidencia a função que a prisão assumiu de gerir a miséria.

Pesquisa realizada pelo FBSP (2018, p. 70) indica, por exemplo, que, no caso de roubo, $86,8 \%$ das prisões em flagrante são convertidas em prisão provisória, enquanto no furto, $30,2 \%$ são convertidas, e na receptação, 36,8\%. Observamos que, nesses dois últimos casos, de crimes cometidos sem violência, os índices de decretação da prisão preventiva superam os índices referentes a crimes de lesão corporal (26,3\%) e se aproximam dos índices relativos a crimes que envolvem violência doméstica (39,8\%).

Outro meio de operar a seleção pelo sistema penal cautelar é o uso da periculosidade do sujeito como justificativa da decretação de prisão preventiva pelas autoridades judiciárias. Pesquisa feita pelo IBADPP em convênio com o TJ/BA (2017, p. 32), sobre as audiências de custódia realizadas em Salvador, aponta que, das 285 decisões analisadas que decretaram prisão preventiva, 114 fizeram referência à periculosidade do sujeito como fundamento, em conjunto ou não com os requisitos legais. Ademais, em 103 situações a gravidade em abstrato do delito e em 199 casos o receio da reiteração criminosa foram fundamentos para decretar a prisão. De fato, a periculosidade do sujeito é usada como fundamento genérico para decretar a cautelar, justificada, muitas vezes, pela garantia da ordem pública, outro conceito extremamente abrangente.

O paradigma racial da periculosidade, concebido na criminologia positivista, é o fio condutor do controle social dos indesejáveis, ao proporcionar falsa cientificidade aos discursos elitistas e racistas proferidos no senso comum. Os postulados dos positivistas ainda legitimam o uso dos estereótipos e estigmas sociais e raciais pelas autoridades judiciárias como justificativa para rotular determinado sujeito como perigoso e encarcerá-lo cautelarmente, antes mesmo de uma sentença condenatória (GÓES, 2014).

Para verificar a seletividade penal dentre os casos que compõem o objeto da presente pesquisa, extraímos da base de dados fornecida pela DPE/BA, acerca das audiências de custódia realizadas em Salvador, em 2018, quantificações sobre características raciais e sociais dos sujeitos flagranteados pelo delito de furto. Apresentamos a seguir os números e 
nomenclaturas conforme constam na sistematização feita, sem quaisquer alterações de como foram dispostos ${ }^{4}$.

Com relação ao perfil racial, das 477 pessoas presas em flagrante, 2 foram identificadas como pretas, 288 como pardas e 87 como negras, sem esclarecimento se eram pardas ou pretas, ao passo que apenas 2 foram identificadas como brancas e 1 como amarela. Por fim, 97 tiveram a raça/etnia não identificada no auto de prisão em flagrante. A identificação dessas características é feita pela autoridade policial. Portanto, não há como se precisar se a identificação racial é baseada na autodeterminação ou na heterodeterminação. Destacamos que, na cidade cuja população é identificada como $45,6 \%$ parda, $36,5 \%$ preta e $17,1 \%$ branca (IBGE, 2017 ), dentre as 380 pessoas alcançadas pelas autoridades policiais com alguma identificação racial, apenas 2 (0,52\%) foram identificadas como brancas, enquanto as outras $98,68 \%$ foram identificadas como negras. Verifica-se, portanto, a sub-representação das pessoas brancas, enquanto uma sobrerepresentação das pessoas negras.

Em pesquisa sobre discriminação racial na abordagem policial, que objetivou verificar em que medida a cor da pele constitui fator de suspeição, após análise de Boletins de Ocorrência (BOs) e entrevistas com Policiais Militares em Pernambuco, Geová da Silva Barros (2008, p. 150) concluiu que:

Nos BOs, quando se confrontaram os registros oriundos da iniciativa própria dos policiais, nos municípios de Olinda, Paulista e Recife, com a população desses municípios, constatou-se que, nas abordagens, os brancos foram sub-representados nos três municípios, os pardos apareceram sub-representados em Paulista e sobre-representados em Recife e Olinda, enquanto os pretos foram sobre-representados nas três localidades, havendo assim indícios da realização da filtragem racial.

$[\ldots]$

4 Conforme o Instituto Brasileiro de Geografia e Estatística (IBGE; 2010), a cor ou raça pode ser identificada como branca, preta, parda, amarela, indígena ou sem declaração. No entanto, utilizamos o termo "negro" em alguns casos para indicar como foi adotado por diversos policiais, em outros para englobar as categorias "pretos" e "pardos". 
Ao se discutir o racismo institucional na comunidade policial, verificou-se que $65,05 \%$ dos profissionais percebem que os pretos são priorizados nas abordagens policiais, o que corrobora as percepções dos alunos do CFO e CFSD, com 76,9\% e 74\%, respectivamente. Com isso, a comunidade policial percebe a existência da filtragem racial.

No aspecto de gênero, 404 sujeitos foram identificados como homens (85\%) e 73 como mulheres (15\%). Embora as mulheres constituam um grupo quantitativamente minoritário, suas especificidades são qualitativamente relevantes, pois o sistema prisional é construído pela ótica patriarcal na qual a regra é o masculino. Isso faz com que as mulheres encarceradas vivenciem formas de violência diferentes das existentes nas prisões masculinas (DAVIS, 2018). No entanto, o marcador de gênero não constituiu objeto desta pesquisa.

Com relação ao marcador da classe social, houve uma dificuldade maior de determiná-lo apenas por meio do parâmetro da renda média, pois, em 259 ocasiões, não houve informação a respeito desse critério. Nas demais 218 situações, ela foi informada como inexistente em 65, chegava até 1 salário mínimo em 142 e ficava entre 1 e 2 salários mínimos em 11, mas ninguém informou renda maior do que 2 salários mínimos. Esses dados já indicam que os sujeitos estão nas categorias socioeconômicas mais baixas. Contudo, operou-se uma análise em conjunto com a escolaridade e com o local de residência, para delimitar com mais precisão a classe social dessas pessoas.

Assim, ao somar os sujeitos que se reconhecem como analfabetos/sem escolaridade/com educação rudimentar (31), com $1^{\circ}$ grau incompleto (178), $1^{\circ}$ completo (44) e $2^{\circ}$ incompleto (34), temos 287 pessoas. Por outro lado, os que informaram ter $2^{\circ}$ grau completo (38), ensino superior incompleto (7) e os que concluíram o ensino superior (2) perfazem um total de 47. Não informaram o grau de escolaridade, 143. Logo, o fato de que pelo menos $60 \%$ das pessoas presas em flagrante não concluiu o $1^{\circ}$ grau permite amparar a hipótese de que esses sujeitos pertencem a grupos socioeconômicos mais vulnerabilizados da sociedade.

A análise do local de residência foi mais trabalhosa, pois foram citados 120 bairros ou regiões diferentes. Destaca-se que 85 pessoas informaram 6 bairros como local de residência: Fazenda Coutos/Vista 
Alegre (21), Pernambués (18), Plataforma (16), Paripe (10), Itapuã (10) e Nordeste de Amaralina (10), os quais foram citados com mais frequência. Além disso, 61 pessoas (12,8\%) informaram não possuir residência, sendo classificadas como "moradores de rua".

Dentre os 6 bairros, Fazenda Coutos, o mais citado, possui a maior porcentagem de habitantes identificados como pretos $(36,2 \%)$ ou pardos $(54,4 \%)$, totalizando $90,6 \%$, e a menor renda média dos responsáveis por domicílios particulares, cerca de $\mathrm{R} \$ 644,80$. Ao passo que Itapuã possui a maior renda média entre eles, de $\mathrm{R} \$ 2.382,20$, e a menor porcentagem de moradores pretos $(27,3 \%)$ ou pardos $(50,7 \%)$, total de $78 \%$. Os demais ficaram entre essas faixas de renda e cor/raça, em uma relação inversamente proporcional entre renda média e porcentagem de moradores pretos ou pardos, conforme dados da Companhia de Desenvolvimento Urbano do Estado da Bahia (CONDER, 2016).

Quanto à faixa etária, 91\% das pessoas possuíam até 45 anos na data do flagrante, sendo que 149 pessoas tinham entre 18 e 25 anos, 161 entre 26 e 35, 126 entre 36 e 45, 27 tinham mais que 45 anos e 14 pessoas não informaram data de nascimento ou idade.

O conjunto de indicadores aponta que o público-alvo da seletividade penal pelas agências policiais é composto, majoritariamente, por homens, identificados como negros, com renda mensal inexistente ou de até 1 salário mínimo, com até 45 anos de idade e com $1^{\circ}$ grau incompleto. Tais dados contribuem para ratificar o afirmado por Baratta (2002) acerca da desigualdade por excelência do sistema penal, vez que a etiqueta de criminoso é um privilégio negativo, distribuído desigualmente na sociedade, com base em aspectos sociais, e, no contexto brasileiro, raciais (FLAUZINA, 2006; GOES, 2014). Na prática, verifica-se uma perseguição mais intensa das agências policiais sobre um determinado público alvo, de homens, jovens, negros e pobres.

\subsection{As DECISÕES QUE DECRETARAM PRISÕES PREVENTIVAS EM NÚMEROS}

Antes de analisar o conteúdo, apreciamos também os dados quantitativos dos 67 processos das pessoas que tiveram a prisão preventiva decretada em audiência de custódia somente pelo crime de furto, para verificar quem foram os sujeitos encarcerados dentre os 477 casos 
analisados. Com o acesso à base de dados do relatório da DPE/BA (2019), foram separados os principais dados a seguir apresentados.

No que tange às características étnicas/raciais dos sujeitos selecionados para responder ao processo em encarceramento provisório, 41 foram identificados como pardos, 11 como negros, 1 como preto, 2 como brancos e 12 não tiveram essa identificação. Os 79\% de pessoas presas preventivamente identificadas como negras indicam o afirmado por Góes (2017, p. 21), que o judiciário transforma o cárcere no "local do negro". Ademais, foram apontados como 59 homens (88\%) e 8 mulheres (12\%). Destaca-se também que 15 pessoas tinham entre 18 e 25 anos, 31 entre 26 e 35, 18 entre 36 e 45 e 2 tinham mais que 45; apenas 1 pessoa não teve a idade informada.

Diante do marcador de classe social, verificou-se que a renda média era inexistente em 7 casos e chegava em até 1 salário mínimo para 28 pessoas; para os demais 32, ela não foi informada. Quanto à escolaridade, 25 sujeitos informaram ter $1^{\circ}$ grau incompleto, 7 o completaram, 2 afirmaram ter começado o $2^{\circ}$ grau e não concluíram, 9 o concluíram, 1 tem ensino superior incompleto e 4 não têm escolaridade ou possuem educação rudimentar; 19 não informaram. Assim, observa-se que grande parte das pessoas possuía renda mensal de até 1 salário-mínimo (52\% do total, equivalente a todas que informaram renda) e até o $2^{\circ}$ grau incompleto (50\%).

Destaca-se também que 12 pessoas que foram informadas como "moradores de rua" (18\%). Ademais, além dos municípios de Lauro de Freitas (4) e de Camaçari (2), os bairros de Salvador mais informados como locais de residência foram Cajazeiras (3), Federação (3), Massaranduba (3), Nordeste de Amaralina (3), Boca do Rio (2), Castelo Branco (2), Cosme de Farias (2), Itapuã (2), Liberdade (2), Paripe (2), Ribeira (2), Sete Portas/Barbalho (2), Sussuarana (2) e Uruguai (2).

Dentre esses, Sete Portas/Barbalho possui a maior renda média dos responsáveis por domicílios particulares $(\mathrm{R} \$ 2.544,4)$ e a menor porcentagem de habitantes identificados como pretos (16,9\%) ou pardos $(53,5 \%)$, total de $70,4 \%$. Sussuarana, por sua vez, possui a menor renda média ( $\mathrm{R} \$ \mathrm{R} \$ 985,4)$ e a segunda maior porcentagem de moradores pretos $(34,9 \%)$ ou pardos $(52,7 \%)$, totalizando $87,4 \%$; sendo a maior de Cosme de Farias, com $37 \%$ habitantes identificados como pretos e 51,4\% como 
pardos (total de $88,4 \%$ ), com renda média de $\mathrm{R} \$ 1.104,0$. Os demais bairros ficaram entre essas faixas (CONDER, 2016).

Tais dados indicam que grande parte da seleção já fora operada pelas agências policiais, porta de entrada do sistema penal brasileiro (ZAFFARONI, 2014; WANDERLEY, 2017). Com relação à seleção feita pelas agências judiciais, na escolha daqueles que respondem ao processo em liberdade ou não, predominou o encarceramento cautelar de pessoas identificadas como pardas, negras ou pretas (53), homens (59), com menos de 45 anos (64), com renda mensal de até 1 salário mínimo (35) e tendo completado no máximo o $1^{\circ}$ grau (34).

Apesar da seleção judicial ter sido limitada pela seleção policial, uma vez que é a polícia que apresenta às autoridades judiciárias os sujeitos a serem julgados, há a reprodução de um determinado público-alvo da distribuição desigual do estigma de criminoso, corroborando o discurso de Baratta (2002).

\section{RAÇA E CLASSE NA FUNDAMENTAÇÃO DA PRISÃo PREVENTIVA POR FURTO EM SALVADOR}

Após as etapas anteriores, debruçamo-nos sobre o conteúdo das 67 decisões proferidas em audiências de custódia em Salvador, em 2018, nas quais houve a decretação de prisão preventiva apenas pelo delito de furto, com base no método apresentado por Bardin (1977), o qual permite certa liberdade na pesquisa. Para tanto, destacamos, nas decisões dos órgãos julgadores, trechos utilizados para justificar a prisão dos sujeitos.

Assim, poderemos discutir, em conjunto com dados quantitativos sistematizados, os fatores que determinaram as medidas cautelares adotadas.

\subsection{Periculosidade do SUJeIto e A NeCESSIDADE DE INIBIR A REITERAÇÃo DELITIVA}

De início, em todas as ocasiões, as autoridades judiciárias apontaram para a necessidade de decretar a cautelar prisional como forma de impedir a reiteração delitiva, fundamentando na periculosidade do sujeito ou no fundado receio de reiteração criminosa, em alguns casos 
em ambas. Apesar de, em alguns casos, os órgãos julgadores se referirem a circunstâncias pessoais dos sujeitos ou do delito em concreto para justificar tais fundamentos, tais termos, frequentemente, foram usados com enorme abstração, sem qualquer referência a elementos específicos da situação fática analisada.

Ademais, em geral, o argumento da perigosidade, usado para legitimar a cautelar, foi associado à necessidade de garantir a ordem pública, de preservar a paz social ou de garantir a aplicação da lei penal, como no seguinte trecho:

Assim, como forma de evitar a reiteração de atos desta natureza pelo Acusado, portanto, afigura-se pertinente a permanência da segregação, com espeque na garantia da ordem pública e da aplicação da Lei Penal, não se revelando, neste momento, indicada a sua soltura (APF nº 0347584-45.2018.8.05.0001).

Os dois primeiros são conceitos gerais e abstratos associados ao ideal de defesa social, de proteger a sociedade daquele sujeito que está sendo julgado, mesmo antes da condenação, em um exercício de previsão dos riscos decorrentes da liberdade. Em nome da segurança pública, justificam-se prisões, torturas e assassinatos, conceito, historicamente, utilizado para legitimar opressões (BATISTA, 2013).

Por sua vez, a garantia da aplicação da lei penal se refere à manutenção da prisão para que, se a pessoa for posteriormente condenada por sentença definitiva, ela não possa escapar da aplicação da pena, ou tenha a possibilidade reduzida. Prende-se cautelarmente para garantir a prisão definitiva. Porém, esse fundamento esconde a possiblidade de ser proferida sentença absolutória, caso em que as prisões serão verdadeiramente inúteis ou sem crime, efetivos sequestros do Estado (ZAFFARONI, 2013).

Com relação ao fundamento da periculosidade, foram encontradas diversas motivações acerca do que seriam indícios efetivos dessa probabilidade de prática de novos crimes. Nas 24 situações em que houve a caracterização de reincidência, houve a associação quase automática com a existência de periculosidade. Nas fundamentações das decisões, foram encontradas diversas afirmações convictas de que o sujeito em liberdade, posto que reincidente, voltaria a delinquir ou que escolheu continuar na prática de atividades criminosas, conforme o trecho destacado: 
No caso presente, portanto, entendo que, por ora, não se impõe a concessão de liberdade provisória ao Acusado, haja vista a reiteração de suas condutas delitivas, fazendo desta atividade o seu modo de vida, destacando-se a extensa ficha criminal que o mesmo ostenta, conforme consta às pgs. $25 / 27$, já tendo sido, inclusive, condenado por duas vezes pela prática de tal crime, o que denota que, se solto, voltará a delinquir. Assim, os elementos colacionados ao APF demonstram a necessidade da segregação cautelar do conduzido (APF n ${ }^{\circ}$ 0335733-09.2018.8.05.0001).

Nota-se como as agências judiciais atuam nos processos de seleção secundária para atribuir ao sujeito condenado por crime anterior uma etiqueta da qual ele dificilmente conseguirá se livrar. Esse estigma possui forte valoração negativa desde os processos de criminalização primária, diante do peso que a lei atribui à reincidência, utilizada para justificar as prisões preventivas, para aumentar a pena, negar a substituição da pena por restritivas de direitos, dentre outros "benefícios" negados.

No entanto, mesmo sem reincidência, houve fundamentação na periculosidade do sujeito. Em 27 ocasiões, a mera existência de antecedentes criminais, ações penais em curso ou outras prisões preventivas decretadas foram consideradas indícios suficientes de risco de reiteração delitiva por parte do sujeito, como no seguinte caso:

Ajunte-se que, da análise do documento de fl 23 , verifica-se que a ficha de antecedentes criminais do Flagranteado é vasta, retratando a reiteração na prática ilícita, indicando que é dotado de elevada periculosidade concreta e possui tendência à prática de delitos, sobressaindo o fundado receio de reiteração criminosa, demonstrando assim que, nesse momento, livre e solto, significa risco à ordem pública (APF nº 0342166-29.2018.8.05.0001).

Há caso no qual a ficha de antecedentes criminais teve o condão de demonstrar ao órgão julgador que o sujeito "atesta história de vida caracterizada pela delituosidade, já tendo ele dado mostras de haver optado pela criminalidade como estilo de vida, podendo vir a cometer novos delitos da mesma espécie" (APF no 0341277-75.2018.8.05.0001).

Nas demais 16 decisões, as justificativas foram de grande abstração, sem menção a antecedentes ou reincidência. Em uma delas, a 
autoridade judiciária expressamente afirmou tratar de sujeito réu primário, mas diante dos "indícios de comando volitivo concernente à continuidade da prática delitiva" decidiu decretar a prisão cautelar, pois "sua liberdade, neste momento, pode representar, em tese, obstrução para a instrução criminal, bem como a necessidade de manutenção da ordem pública” (APF $n^{\circ}$ 0308637-19.2018.8.05.0001).

A inexistência de antecedentes criminais não obsta que o órgão julgador afirme com convicção que a pessoa já praticou outros delitos, assim como que dedica sua existência a atividades criminosas. O princípio da presunção de inocência é flexibilizado a ponto de o sujeito ser considerado, mesmo sem qualquer condenação criminal, um indivíduo absolutamente incapaz de conviver livremente em sociedade. A liberdade do sujeito é posta como secundária, diante do dever do julgador de defender a sociedade:

Este plantonista procura evitar que o delinquente continue enveredando pelo caminho irracional e repugnante da criminalidade latente, seja contra a vítima e/ou outras pessoas da nossa sociedade já tão sofrida, porque, diante do contexto jurídico até aqui apresentado, o meliante é dotado de elevada periculosidade e inclinação na atividade criminosa (APF $n^{\circ}$ 0316548-82.2018.8.05.0001).

Além disso, em cinco decisões, a prisão foi fundamentada em aspectos específicos do modus operandi ${ }^{5}$, isoladamente ou em conjunto com a reincidência ou com maus antecedentes. Em uma delas, foi considerado como indício de reiteração delitiva o fato de que "embora não tenha sido apreendido o objeto do furto, constou do auto de exibição e apreensão, a arrecadação de vários objetos e documentos alheios em poder do flagranteado" (APF $n^{\circ}$ 0303916-24.2018.8.05.0001). Como o indivíduo não era reincidente nem possuía antecedentes criminais, o órgão julgador justificou a periculosidade no fato em si, para então legitimar seu encarceramento cautelar.

Em outro caso, afirmou-se que "trata-se de crime praticado com utilização de chave falsa, que em si revela a potencialidade do delito e,

5 Expressão comumente adotada pelos órgãos julgadores para se referir ao modo de operar, executar ou praticar o fato tido como criminoso. 
pois, a necessidade e a adequação da custódia cautelar do Inculpado". Circunstância essa que, no entendimento da autoridade judiciária, demonstra que "não se permite tolerar o retorno do Flagranteado ao seu convívio, ao menos temporariamente" (APF $\mathrm{n}^{\circ}$ 0300800-10.2018.8.05.0001).

Em outra decisão, a existência da reincidência foi levada em consideração também em conjunto com aspectos específicos e concretos do delito investigado. No caso, tendo em vista que o sujeito flagranteado foi acusado de ter quebrado o vidro de um veículo para subtrair os bens que estavam em seu interior, conforme trecho em destaque:

Com efeito, o flagranteado quebrou o vidro de um carro para praticar furto e conforme certidão do sistema saj responde a inúmeros processos por crimes da mesma natureza, sendo inclusive reincidente específico pois já foi condenado por delito de natureza patrimonial (APF $\mathrm{n}^{\circ}$ 0305125-28.2018.8.05.0001).

Em um caso, argumentou-se como indicativo de "contumácia na prática delitiva" o fato de que as acusadas subtraíram "mercadorias em lojas de departamento utilizando um revestimento metálico no interior da bolsa para impedir o disparo do alarme" (APF n ${ }^{\circ}$ 0313250-82.2018.8.05.0001), em conjunto com os antecedentes criminais.

A reincidência foi o principal fator que levou à afirmação de que o indivíduo é perigoso para a sociedade e à alegação da necessidade de inibir a reiteração delitiva. Apesar disso, antecedentes criminais, outras ações penais em curso ou outras prisões preventivas decretadas também serviram de fundamento; assim como circunstâncias relacionadas ao fato.

Ao afirmar que o sujeito é perigoso para a sociedade e que demonstra risco de reiteração delitiva, de modo que deve ser segregado e encarcerado, as condutas são reduzidas a escolhas e decisões tomadas pelo indivíduo, com o argumento de que em liberdade vai continuar repetindo as mesmas decisões, porque é inclinado ao crime ou adota a criminalidade como estilo de vida. Nesse sentido, não se vê menção a fatores externos que possam ter contribuído para que o fato seja classificado como criminoso ou para que o sujeito tenha sido selecionado pelas agências policiais. Apenas se afirma que a pessoa é incapaz de permanecer em convívio pela sociedade e deve ser isolada. 
3.2 AUSÊNCIA DE ENDEREÇO CERTO E A IMPOSSIBILIDADE DE IDENTIFICAÇÃO CRIMINAL

Em algumas decisões, as autoridades judiciárias fizeram questão de ressaltar que "o fato do agente ser primário e ter residência fixa, não lhe garante alvará permanente de impunidade" (APF n ${ }^{\circ}$ 034127775.2018.8.05.0001). Entretanto, a ausência de endereço certo ou de informação acerca de um local específico em que o indivíduo fosse encontrado foi o argumento utilizado em quatro decisões para justificar a prisão preventiva.

Em uma ocasião, a autoridade judiciária deixou claro que "foi confessado pelo mesmo que é morador de rua, o que dificulta a decretação da liberdade provisória” (APF no 0324464-70.2018.8.05.0001). Em outro, foi decretada a prisão, pois "o mesmo não tem endereço certo e, em audiência de custódia, não soube declinar um local específico para que pudesse ser encontrado e cientificado dos atos processuais além de não possuir trabalho fixo" (APF $n^{\circ}$ 0303472-88.2018.8.05.0001).

Foram considerados requisitos autorizadores da cautelar prisional, em uma terceira decisão, o fato de o investigado possuir "maus antecedentes, não ter residência fixa nesta cidade e ser usuário de drogas” (APF $\mathrm{n}^{\mathrm{o}}$ 0343878-54.2018.8.05.0001). No último desses casos, a "circunstância de ausência de especificação de domicílio ou residência certa para ser encontrado" foi associada com o suposto "vínculo perene com o distrito da culpa" (APF no 0348923-39.2018.8.05.0001).

Nesse contexto, há o entendimento de que como a pessoa não pode ser encontrada em liberdade, ela deve responder ao processo preso, para que o sistema judicial tenha ciência de sua localização. Entretanto, o código processual penal traz a previsão de medidas cautelares que poderiam sanar essa dificuldade de localização, como a prevista no art. 319, I, que corresponde ao "comparecimento periódico em juízo, no prazo e nas condições fixadas pelo juiz, para informar e justificar atividades”.

Não estamos aqui defendendo a aplicação dessa medida, uma vez que, como demonstrado por Romão (2019), a liberdade precária e condicionada, especialmente relacionada às populações de rua, é constantemente manejada como uma concessão bondosa da autoridade judiciária, em busca de ideais retributivistas e correcionalistas. O vocabulário utilizado nessas decisões, quando se fala em decretar a prisão preventiva ou conceder a 
liberdade provisória, demonstra que não decretar a cautelar prisional é considerado uma benesse, uma permissão, uma concessão do órgão julgador.

Quando aplicadas medidas cautelares diversas da prisão, não são asseguradas a essas pessoas as condições efetivas de cumpri-las, como garantir uma passagem de ônibus para que possam comparecer em juízo mensalmente. A medida, portanto, é aplicada como uma espécie de ato concessivo, mas já com a expectativa de ser descumprida, a ponto de ser posteriormente decretada a cautelar (ROMÃO, 2019, p. 154-155). Na prática, diante do argumento de que "as medidas cautelares diversas da prisão se revelam ineficazes" (APF $\mathrm{n}^{\mathrm{o}}$ 0303472-88.2018.8.05.0001), legitima-se a necessidade de encarcerar o sujeito sem ao menos explicar o motivo dessa ineficácia. Prende-se primeiro e justifica-se depois, sem preocupação com a descarcerização responsável, um dos objetivos da audiência de custódia. Assim, medidas cautelares diversas da prisão cumprem função de redução de danos, para, ao menos, tentar evitar que a pessoa seja submetida à opressão prisional.

Há uma dupla violência estatal contra os sujeitos "moradores de rua” ou que não informam um endereço em que podem ser encontrados. Pois tendo conhecimento dessa circunstância, não há qualquer exercício de compreensão pelos juízes acerca das condições e opressões enfrentadas, nem pelo Estado, que deveria sanar a falta de moradia digna, direito constitucionalmente assegurado a todos. Apesar disso, a ausência de um lugar para morar é conhecida pelo órgão julgador para ser valorada negativamente e fundamentar a necessidade de se prender preventivamente $o$ sujeito, para que se torne possível a sua participação no processo e, caso condenado, a posterior aplicação da pena.

A análise do conteúdo em conjunto com os dados quantitativos revela a incidência da seleção penal quanto ao marcador de classe e a desigualdade por essência do sistema penal, expressamente com relação ao argumento da ausência de residência declarada. Ademais, pois, dentre os 67 casos, em 35 a renda mensal não passava de 1 salário mínimo e 12 pessoas foram identificadas como "moradores de rua".

\subsection{ONDE ESTÁ O ASPECTO RACIAL?}

Dentre as diversas justificativas adotadas para afirmar, com elevado grau de convicção, que o indivíduo investigado solto voltaria a 
delinquir, não verificamos, em nenhuma das decisões investigadas, menção expressa ao perfil étnico ou racial do sujeito como forma de fundamentar sua periculosidade. Apesar disso, o encarceramento cautelar foi decretado predominantemente para pessoas identificadas como pardas, negras ou pretas (53). Conforme pontua Dina Alves (2017, p. 113-114):

Mais uma vez, os jargões jurídicos "personalidade desajustada e perigosa", "personalidade incompatível com o convívio social" demonstraram que, embora raça, como categoria biológica, seja um tabu nos discursos punitivos, juízes adaptam, conscientes ou inconscientemente, os discursos racializados em pressupostos subjetivos para justificar punições e criminalizar os grupos vulneráveis.

O alto grau de abstração das decisões nas quais a prisão preventiva é decretada com base na periculosidade esconde a persistência de estigmas raciais e sociais para aferir quem são os sujeitos perigosos, que devem ser segregados e neutralizados. Com base na neutralidade racial propagandeada pelo Judiciário, a distribuição desigual do estigma da criminalidade na sociedade é silenciada. O colorblindness (cegueira ou daltonismo de cor) permite a reprodução de desigualdades sob a justificativa de que o "encarceramento em massa é oficialmente indiferente à raça” (ALEXANDER, 2018, p. 263).

Percebemos tanto na atuação prática das agências policiais quanto das judiciais, o pressuposto revelado por Flauzina (2006) e Góes (2014), segundo o qual o sistema penal brasileiro não funciona para inibir condutas criminosas, mas cumpre uma função racista de selecionar os indivíduos que serão encarcerados e segregados por serem "perigosos". As autoridades judiciárias relegitimam a seleção operada pela polícia, enquanto mantêm a aparência de que controlam os abusos policiais, em nome da neutralidade da justiça.

Conforme Lages e Ribeiro (2019), há a crença comum de que o judiciário é imune às desigualdades estruturais existentes na sociedade brasileira, que a lei é aplicada igualmente para todos. Essa suposta igualdade formal oculta que a seleção policial extraí dos grupos raciais e sociais oprimidos o público-alvo do controle penal. Dessa maneira, a audiência de custódia cumpre um papel nessa ilusão, uma vez que ela aumenta a aparência de legalidade e justiça, bem como esconde a seletividade no 
encarceramento preventivo e o uso exacerbado dessa cautelar justificada no ideal de defesa social.

No entanto, como já abordado, a origem do complexo industrial-prisional remonta à escravidão, de modo que a perseguição aos crimes patrimoniais serve ao propósito de manter o controle social, econômico e racial, e reproduzir as desigualdades existentes por meio do encarceramento em massa (DAVIS, 2018). No contexto brasileiro, após a abolição da escravidão, o sistema prisional assume o papel de controle dos corpos não brancos, mesmo com status formal de seres humanos livres. Desse modo, o poder punitivo se torna um instrumento da pequena elite branca para manter a exploração desses corpos indesejados e preservar a acumulação patrimonial (FLAUZINA, 2006).

A seleção penal começa na criminalização primária, com a estipulação de graves penas para crimes de ordem patrimonial, ao lado dos delitos relacionados ao tráfico ou uso de entorpecentes, por serem ameaças à acumulação de capital pela elite (BARATTA, 2002). Depois, há um reforço pelas agências policiais e judiciais, na criminalização secundária, de perseguirem intensamente praticantes de tais condutas, especialmente quando pertencentes aos grupos sociais historicamente oprimidos (ZAFFARONI, 2013).

Acreditamos, em verdade, que a seleção penal começa ainda antes, com a omissão estatal de assegurar condições dignas de vida aos corpos "indesejados". Há uma intersecção entre os marcadores de raça e classe, pois os corpos negros compõem a maior parte da população carcerária brasileira, mas fora das prisões são também a maior parte das pessoas em condição de vulnerabilidade social (ALVES, 2017; IBGE, 2010). Portanto, há uma maior chance desses indivíduos serem selecionados pelo sistema punitivo tanto pela sua cor de pele, quanto pela sua classe social, uma vez que, diante dos dados desta pesquisa, pessoas negras são a maioria dos moradores dos bairros de Salvador nos quais a seleção policial incidiu com maior violência, mais de $78 \%$.

Prende-se o "morador de rua" por ter furtado algo, mas se ignoram as circunstâncias e as violências cotidianas a que está submetido. Da mesma forma, é decretada a prisão para um indivíduo negro pela sua reincidência, mas silencia-se o fato de que as pessoas não-brancas recebem o privilégio negativo do estigma da criminalidade. Após o primeiro contato 
com o sistema criminal, quando as agências penais selecionam novamente alguma dessas pessoas, em razão da reincidência, atribuem-lhe as etiquetas de perigosas, tendentes a criminalidade e inaptas à vida em sociedade.

Pessoas negras são majoritariamente selecionadas pelas agências policiais, levadas até as agências judiciais e presas sob o argumento de que sua manutenção em liberdade apresenta elevado risco à paz social. A associação de pessoas negras à criminalidade, ao perigo é feita muitas vezes não intencionalmente (BARROS, 2008; PIRES, LYRIO, 2014; WANDERLEY, 2017). O racismo escondido no discurso é encontrado institucionalizado na atuação prática do sistema:

O racismo institucional aparece como um sistema generalizado de discriminações inscritas nos mecanismos rotineiros, assegurando a dominação e a inferiorização dos negros sem que haja necessidade de teorizá-la ou justificá-la pela ciência.”. (PIRES, LYRIO, 2014, p. 9)

A adoção do discurso da periculosidade pelo controle penal permite que a autoridade judiciária mantenha a aparência de neutralidade racial, ao tratar da reincidência, de circunstâncias do modus operandi ou de antecedentes criminais como indícios de perigosidade, ao passo que encarcera, de forma acentuada, homens, negros, jovens e pobres. O sistema vigente é mais sofisticado do que a racionalidade da criminologia positivista, pois permite a manutenção do papel funcional do sistema punitivo no extermínio da população negra, sem precisar ser abertamente racista, uma vez que há outros elementos da estrutura social e do sistema penal que reproduzem as hierarquias sociais e raciais.

Entendemos que o que leva o órgão julgador a assegurar que o sujeito investigado é tão perigoso a ponto de ser urgente o seu encarceramento para proteger a paz social não são os aspectos afirmados na fundamentação das decisões. Tanto que muitos se furtam a esse trabalho de buscar motivações e recorrem a frases de alta abstração, como dizer que a prisão é importante para inibir a reiteração delitiva.

Além disso, o uso da periculosidade, de forma extremamente ampla, também tem como objetivo apresentar uma ilusória sensação de justiça e segurança para a sociedade. O elevadíssimo número de pessoas que se encontram em situação prisional no Brasil dá a aparência de um rigoroso sistema penal, que segrega aqueles que trazem risco social, 
quando, em realidade, o encarceramento em massa cumpre sua função de manutenção de desigualdades.

Apesar de não verificar de forma explícita a presença do marcador racial no conteúdo das decisões, por meio da análise conjunta dos aspectos quantitativos e dos qualitativos, foi possível compreender de maneira mais ampla a seletividade penal com base nesse fator, considerando a existência de um racismo institucional. Na investigação das agências judiciais, averiguamos que, além da presença do estigma da periculosidade no controle social dos oprimidos, há um contexto de racismo não abertamente declarado, mas que reproduz relações de poder em continuidade das relações raciais coloniais.

\section{Considerações Finais}

Diante do fenômeno da seletividade penal, a presente pesquisa constituiu uma investigação empírica da sua ocorrência na prática jurídica soteropolitana, em especial do uso da periculosidade como termo abstrato para fundamentar as prisões preventivas. A investigação se debruçou apenas sobre as audiências de custódia em Salvador, no ano de 2018, e sobre os delitos de furto, para tentar responder o seguinte questionamento: quais os principais fatores considerados na fundamentação do juízo de periculosidade na decretação das prisões preventivas? Houve também a proposição de verificar a presença de argumentos racistas ou classistas nesse juízo cautelar.

Pela ótica da criminologia crítica, partimos da premissa de que o crime não é uma característica ontológica da pessoa ou do fato em si, mas um resultado de processos de criminalização e estigmatização. Ademais, pela crítica racial elaborada por Flauzina e Góes, entendemos que tais processos levam em consideração especialmente marcadores de raça, já que a sociedade brasileira é historicamente estruturada na escravidão e no racismo. Assim, tomamos como a operatividade real do sistema punitivo brasileiro a de selecionar seu público-alvo das classes mais baixas e de um grupo racial determinado.

Com relação ao método, operamos uma análise documental, com o delineamento de uma pesquisa quantitativa das 477 decisões proferidas em audiência de custódia por furto, em Salvador, no ano de 2018, em conjunto com a análise de conteúdo das decisões que decretaram prisões preventivas. 
As pessoas flagranteadas e levadas à audiência de custódia, bem como as 67 cautelarmente encarceradas, eram majoritariamente identificadas como homens, negros, com renda mensal de até 1 salário mínimo, com até 45 anos de idade e sem escolaridade ou $1^{\circ}$ grau incompleto. Dentre essas 67 pessoas, 53 foram identificadas como negras e apenas 2 como brancas; 59 como homens e 8 como mulheres; 46 tinham menos que 35 anos à época do flagrante; a renda média era inexistente ou menor que 1 salário mínimo para 35 pessoas; a escolaridade era inexistente ou até $1^{\circ}$ grau incompleto em 29 situações; e 12 informaram ser moradores de rua. Em ambas as quantificações, tanto da seleção policial quanto da judicial, verificamos a distribuição essencialmente desigual do sistema penal.

$\mathrm{Na}$ análise de conteúdo dessas 67 decisões, verificamos que para justificar o preenchimento do fundamento legal da garantia da ordem pública ou o da aplicação da lei penal, o juízo frequentemente motiva a necessidade de determinar a cautelar prisional pela existência de periculosidade do sujeito e de necessidade de inibir a reiteração delitiva. Os quais configuram conceitos abertos, que não encontram definição legal e permitem que diversas circunstâncias sejam utilizadas para se afirmar que o indivíduo é perigoso e tende à criminalidade, algumas de grande abstração. Assim, como resposta ao problema de partida observamos que a periculosidade, por sua vez, foi justificada na existência de reincidência, antecedentes criminais, ações penais em curso, outras prisões preventivas decretadas ou indícios de comando volitivo direcionado à prática delitiva.

Diante da hipótese de que além da classe, o racismo é fator determinante, para as autoridades judiciárias afirmarem a periculosidade e decretarem prisões, com relação à questão de classe, não definida apenas pela faixa salarial, mas também pelas condições de moradia, verificamos o uso da ausência de endereço certo, de residência ou de trabalho fixo para legitimar o encarceramento. Há uma dupla violência estatal contra o indivíduo investigado, que já sofre as consequências e dificuldades da vulnerabilidade social e ainda tem essa condição valorada negativamente para justificar sua prisão.

Quanto ao marcador racial, não encontramos fundamentações explicitamente racializadas para justificar tal periculosidade nas decisões. Entretanto, percebemos que o racismo está presente na operacionalidade prática do sistema penal, mas é velado no conteúdo das decisões, uma vez que o sistema atual institucionalizou o racismo de forma que ele não 
precisa ser declarado. Assim, a suposta neutralidade racial do Poder Judiciário permite a manutenção da hierarquização das pessoas com base na raça, aspecto característico das relações coloniais brasileiras, sustentada pelos instrumentos violentos de controle punitivo.

Mesmo que não tenha sido afirmado nada acerca do perfil racial dos sujeitos encarcerados, o fato de 53 dentre 67 que tiveram a prisão provisória decretada em casos de furto em Salvador no ano de 2018 serem identificados como negros revela quem são as pessoas presas por serem supostamente perigosas. Ademais, as pessoas identificadas como negras também foram percebidas como a maior parte dos moradores dos bairros de renda média mais baixa, de onde foram selecionados grande parte dos indivíduos pelo sistema punitivo. Assim, os dados quantitativos apontam para a desigualdade por excelência do sistema prisional, uma vez que são, majoritariamente, os homens, negros, jovens e pobres que recebem o privilégio negativo da vulnerabilidade, da estigmatização e da criminalização. Assim, encarcerados com mais frequência, são também rotulados como reincidentes, perigosos e tendentes à criminalidade com maior intensidade.

Não é necessário que o órgão julgador faça menção à raça do sujeito no corpo da decisão para que sua atuação seja racializada. A institucionalização do racismo tem como instrumentos a manutenção dessas pessoas em condições de desamparo social, a sua seleção pelas agências policiais e, depois, o uso de conceitos abertos para fundamentar uma prisão pela garantia da ordem pública, o que permite que o sistema continue incidindo de forma racialmente seletiva. As autoridades judiciárias, majoritariamente brancas e pertencentes às classes econômicas mais altas, seguem selecionando os sujeitos perigosos que precisam ser segregados e neutralizados dentro dos grupos social e racialmente vulnerabilizados, de forma a manter a subjugação e a opressão dos povos não brancos historicamente explorados e estigmatizados.

\section{REFERÊNCIAS}

ALEXANDER, Michelle. A nova segregação: racismo e encarceramento em massa. Trad. Pedro Davoglio. São Paulo: Boitempo, 2018.

ALVES, Dina. Rés negras, juízes brancos: uma análise da interseccionalidade de gênero, raça e classe na produção da punição em uma prisão paulistana. Revista CS, n. 21, p. 97-120, jan. -abr., 2017. http://dx.doi.org/10.18046/recs.i21.2218 
BAHIA. CONDER. Painel de informações: dados socioeconômicos do município de Salvador por bairros e prefeituras-bairro/Sistema de Informações Geográficas Urbanas do Estado da Bahia (INFORMS - Organizador) 5 ed. Salvador: CONDER/ INFORMS, 2016. 189 p.: il. Color. Fotos. Tabelas. Gráficos. Mapas.

BARATTA, Alessandro. Criminologia Crítica e Crítica do Direito Penal: introdução à sociologia do direito penal. 3. ed. Rio de Janeiro: Revan, 2002.

BARDIN, Laurence. Análise de conteúdo. Trad. Luís Antero Reto e Augusto Pinheiro. Lisboa: Edições 70; São Paulo: Livraria Martins Fontes, 1977.

BARROS, Geová da Silva. Filtragem racial: a cor na seleção do suspeito. Revista Brasileira de Segurança Pública, São Paulo, v.2, n. 1, p. 134-155, jul-ago, 2008. Disponível em: <https://revista.forumseguranca.org.br/index.php/rbsp/article/ view/31/29> Acesso em 29 set. 2020.

BATISTA, Nilo. Criminologia sem segurança pública. Revista Derecho Penal e Criminologia, v. 10, p. 86-90, 2013.

BATISTA, Vera Malaguti. Criminologia e Política Criminal. Passagens: Revista Internacional de História Política e Cultura Jurídica. Rio de Janeiro, v. 1, n. 6, p. 20-39, jul./dez. 2009. https://doi.org/10.5533/1984-2503-20091202

BECKER, Howard Saul. Outsiders: Estudos da sociologia do desvio. Trad. Maria Luíza X. de Bordes. Rio de Janeiro: Zahar, 2008.

BORDIEU, Pierre. Capitalismo Simbólico e Classes Sociais. Novos Estudos CEBRAP, epub, n. 96, p. 105-115, set. 2013. https://doi.org/10.1590/ S0101-33002013000200008

BRASIL, DEPEN. Levantamento Nacional de Informações Penitenciárias. Brasília: Departamento Penitenciário Nacional, Ministério da Justiça e Segurança Pública, 2020.

CAMPENHOUDT, LucVan; QUIVY, Raymond. Manual de investigação em ciências sociais. Trad. João Minhoto Marques, Maria Amália Mendes e Maria Carvalho. 4. ed. Lisboa: Trajectos, 2005.

CELLARD, André. A análise documental. In: POUPART, Jean et al. A pesquisa qualitativa: enfoques epistemológicos e metodológicos. Trad. Ana Cristina Nasser. Petrópolis: Editora Vozes, 2008, p. 295-316.

CONECTAS Direitos Humanos. Tortura blindada: como as instituições do sistema de justiça perpetuam a violência nas audiências de custódia. 2017. Disponível em <https://www.conectas.org/publicacao/tortura-blindada>. Acesso em 27 julho 2021.

CONSELHO NACIONAL DE JUSTIÇA. Mapa Audiência de Custódia. Jun. 2017. Disponível em: <https://www.cnj.jus.br/sistema-carcerario/mapa-audiencia-de-custodia/>. Acesso em: 28 maio 2020. 
DAVIS, Angela. Estarão as prisões obsoletas? Trad. Marina Vargas. Rio de Janeiro: Difel, 2018.

DEFENSORIA PÚBLICA DO ESTADO DA BAHIA (DPE/BA). Relatório das audiências de custódias na comarca de Salvador/BA: anos de 2015-2018. Defensoria Pública do Estado da Bahia. Salvador: ESDEP, 2019.

DUARTE, Evandro Piza. Criminologia e racismo: introdução ao processo de recepção das teorias criminológicas no Brasil. 1988. Dissertação (Mestrado) Centro de Ciências Jurídicas da Universidade Federal de Santa Catarina, Florianópolis, SC. 1988. Disponível em: <https://repositorio.ufsc.br/bitstream/ handle/123456789/77655/139612.pdf?sequence> Acesso em: 8 set. 2021.

DUARTE, Evandro Piza; FREITAS, Felipe da Silva. Corpos negros perseguição do Estado: política de drogas, racismo e direitos humanos no Brasil. Revista de Direito Público, v. 16, n. 89, p. 156 - 179, set. -out 2019. Disponível em: < https://www.portaldeperiodicos.idp.edu.br/direitopublico/article/view/3608>. Acesso em 14 set. 2021.

ELBERT, Carlos Alberto. Manual Básico de Criminologia. Buenos Aires: Editorial Universitária de Buenos Aires, 1998.

FBSP - Fórum Brasileiro de Segurança Pública. Audiência de Custódia, Prisão Provisória e Medidas Cautelares: Obstáculos Institucionais e Ideológicos à Efetivação da Liberdade como Regra. Relatório de pesquisa, 2018.

FLAUZINA, Ana. Corpo negro caído no chão: o sistema penal e o projeto genocida do estado brasileiro. 2006. Dissertação (Mestrado) - Faculdade de Direito da Universidade de Brasília, Brasília, DF, 2006. Disponível em: <http://repositorio. unb.br/bitstream/10482/5117/1/2006_AnaLuizaPinheiroFlauzina.pdf > Acesso em: 17 abr. 2020.

GÓES, Luciano. Racismo, genocídio e cifra negra: Raízes de uma criminologia Antropofágica. In: Criminologias e Política Criminal. Florianópolis: CONPEDI, 2014. Disponível em: <http://www.publicadireito.com.br/artigos/?cod=64600a36d09f4960>. Acesso em: 1 maio 2020.

GÓES, Luciano. A “tradução" do paradigma etiológico de criminologia no Brasil: um diálogo entre Cesare Lombroso e Nina Rodrigues da perspectiva centro-margem. 2015. Dissertação (Mestrado) - Universidade Federal de Santa Catarina, Florianópolis, SC, 2015.

GÓES, Luciano. Pátria Exterminadora: o projeto genocida brasileiro. Revista Transgressões. Natal, RN, v. 5, n. 1, p. 53-79, maio 2017. Disponível em: <https:// periodicos.ufrn.br/transgressoes/article/view/12101>. Acesso em: 1 maio 2020. GIL, Antônio Carlos. Métodos e técnicas de pesquisa social. 6. ed. São Paulo: Atlas. 2008. 
GUIMARÃES, Antônio. Raça, cor, cor da pele e etnia. Cadernos de Campo. São Paulo, SP, v. 20. n. 20, p. 265-271, 2011. https://doi.org/10.11606/issn.23169133.v20i20p265-271

GUIMARÃES, Antônio. Racismo e antirracismo no Brasil. ed. 3. São Paulo: Editora 34. 2009.

INSTITUTO DE DEFESA DO DIREITO DE DEFESA (IDDD). O fim da liberdade: a urgência de recuperar o sentido e a efetividade das audiências de custódia. 2019. Disponível em: <https://iddd.org.br/pesquisa-revela-o-fim-da-liberdade-nas-audiencias-de-custodia/>. Acesso em 27 julho 2021.

IBADPP, TJBA. Relatório final de atividades: grupo de pesquisa sobre audiências de custódia - convênio de cooperação técnico-científica TJ/BA e IBADPP. Salvador, 2017.

IBGE. Censo Demográfico, 2010. Disponível em: <https://biblioteca.ibge.gov.br/ visualizacao/periodicos/93/cd_2010_caracteristicas_populacao_domicilios. pdf>. Acesso em: 23 out. 2020.

IBGE. Desigualdades por cor ou raça em Salvador, "segundo o IBGE”. 2019. Disponível em: <http://generoesexualidade.ffch.ufba.br/wp-content/uploads/2019/04/ apresenta_camara_abr19_semvideo_compressed.pdf>. Acesso em 28 julho 2021.

LAGES, Lívia Bastos; RIBEIRO, Ludmila. Os determinantes da prisão preventiva na Audiência de Custódia: reforço de estereótipos sociais? Revista direito GV. São Paulo, v. 15, n. 3, nov. 2019. https://doi.org/10.1590/2317-6172201933

MUNANGA, Kabengele. Uma abordagem conceitual das noções de raça, racismo e etnia. In: BRANDÃO, André (Org.). Programa de educação sobre o negro na sociedade brasileira. Niterói: Editora da Universidade Federal Fluminense, 2004, p. 15-34.

NICORY, Daniel. A prática da audiência de custódia. Salvador: Juspodium, 2017.

PIRES, Thula; LYRIO, Caroline. Racismo institucional e acesso à justiça: uma análise da atuação do Tribunal de Justiça do Estado do Rio de Janeiro nos anos de 19892011. In: COUTO, Mônica Bonetti et al (Org.). Acesso à justiça I. Florianópolis: CONPEDI, 2014, p. 513-541. Disponível em: <http://www.publicadireito.com. br/artigos/?cod=7bf570282789f279>. Acesso em: 27 julho 2021.

ROMÃO, Vinicius de Assis. Entre a vida na rua e os encontros com a prisão: um estudo a partir das audiências de custódia. 2019. Dissertação (Mestrado) - Faculdade de Direito da Universidade do Estado do Rio de Janeiro, Rio de Janeiro, 2019. Disponível em: <http://www.bdtd.uerj.br/tde_busca/arquivo.php?codArquivo=15858>. Acesso em: 29 set. 2020.

ROMÃO, Vinícius de Assis. A aplicação de medidas cautelares pessoais em audiências de custódia: um olhar a partir da prisão em flagrante de pessoas em situação 
de rua. Revista Brasileira de Direito Processual Penal, Porto Alegre, v. 7, n. 1, p. 611-650, jan./abr., 2021. https://doi.org/10.22197/rbdpp.v7i1.425

SEGATO, Rita Laura. El color de la cárcel em América Latina: apuntes sobre la coloniaidad de la justicia en un continente en desconstrucción. Nueva Sociedade. Buenos Aires, n. 208, p. 142-161, mar./abr. 2007. Disponível em: <https://www. academia.edu/download/56749072/El_color_de_la_c_U00e1rcel_en_Am_U00e9rica_Latina.pdf>. Acesso em: 30 abr. 2020.

WANDERLEY, Gisela Aguiar. Filtragem racial na abordagem policial: a "estratégia de suspeição generalizada" e o (des)controle judicial da busca pessoal no Brasil e nos Estados Unidos. Revista Brasileira de Ciências Criminais, São Paulo, v. 135, ano 25, p. 189-229, set. 2017.

ZAFFARONI, Eugênio Raúl. A questão criminal. Rio de Janeiro: Revan, 2013.

ZAFFARONI, Eugênio Raúl. O inimigo no direito penal. Trad. Sérgio Lamarão. 3. ed. Rio de Janeiro: Editora Revan, 2014.

\section{Additional information and author's declarations (scientific integrity)}

Acknowledgment: O presente estudo foi desenvolvido no âmbito do Projeto de Iniciação Científica (PIBIC) da Universidade Federal da Bahia - UFBA, edital 2019-2020, financiado pelo Conselho Nacional de Desenvolvimento Científico e Tecnológico (CNPq), com apoio da Defensoria Pública do Estado da Bahia (DPE/BA).

Conflict of interest declaration: the authors confirm that there are no conflicts of interest in conducting this research and writing this article.

Declaration of authorship: all and only researchers who comply the authorship requirements of this article are listed as authors; all coauthors are fully responsible for this work in its entirety.

- Bernardo Leão: projeto e esboço inicial (conceptualization), desenvolvimento da metodologia (methodology), coleta e análise de dados (data curation), levantamento bibliográfico (investigation), revisão bibliográfica (investigation), redação (writing - original draft), participação ativa nas discussões 
dos resultados (validation), revisão crítica com contribuições substanciais (writing - review and editing), aprovação da versão final (final version approval).

- Alessandra Prado: projeto e esboço inicial (conceptualization), desenvolvimento da metodologia (methodology) e análise de dados (data curation), levantamento bibliográfico (investigation), revisão bibliográfica (investigation), redação (writing - original draft), participação ativa nas discussões dos resultados (validation), revisão crítica com contribuições substanciais (writing - review and editing), aprovação da versão final (final version approval).

Declaration of originality: the authors assure that the text here published has not been previously published in any other resource and that future republication will only take place with the express indication of the reference of this original publication; they also attest that there is no third party plagiarism or self-plagiarism.

\section{Editorial process dates}

(http://www.ibraspp.com.br/revista/index.php/RBDPP/about/editorialPolicies)

- Submission: 31/07/2021

- Desk review and plagiarism check: 02/08/2021

- Review 1: 15/08/2021

- Review 2: 17/08/2021

- Review 3: 18/08/2021

- Review 4: 29/08/2021

- Preliminary editorial decision: 03/09/2021

- Correction round return: 17/09/2021

- Final editorial decision: 01/10/2021

\section{Editorial team}

- Editor-in-chief: 1 (VGV)

- Associated-editor: 2 (BC, LG)

- Reviewers: 4 


\section{HOW TO CITE (ABNT BRAZIL):}

LEÃO, Bernardo S. C; PRADO, Alessandra R. M. A periculosidade na decretação de prisão preventiva por furto em Salvador: controle racial e de classe. Revista Brasileira de Direito Processual Penal, vol. 7, n. 3, p. 1713-1749, set./dez. 2021. https://doi.org/10.22197/rbdpp.v7i3.627

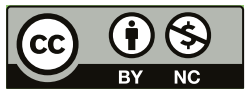

Esta obra está licenciada com uma Licença Creative Commons Atribuição-NãoComercial 4.0 Internacional. 